\title{
Research on Catch-up of China Telecom Manufacturing from Perspective of Industrial Transfer and Organization
}

\author{
Yaozhong Chang \\ Institute of Industrial Economics, Chinese Academy of Social Sciences \\ Beijing, China \\ yzhchang@263.net
}

\begin{abstract}
Present researches on the catch-up of China telecom manufacturing have research gaps that they were not put in the background of international industrial transfer and domestic industry policy to comprehensively and clearly depict catch-up mechanism on basis of industrial economic theories. In this paper, logic analysis framework on mainstream industrial economic theories is constructed, characters of international transfer and domestic industry policy are analyzed, four-phase model of transformation process of latecomers' competition power from absolute disadvantage to absolute advantage is established and game theory is applied to analyze internal relations among industrial transfer, market entry barrier, and enterprise's capacity and conduct. Research result shows that industrial transfer is basis of catch-up, market entry barrier is condition of catch-up, catch-up performance has feedback on them, and comparison result of bargaining cost and coordination cost determines relation mode between foregoer and latecomer. It's suggested that latecomer should set down reasonable target and decision of catch-up according to its capacity and industry development phase, and pay attention to external study but base itself on independent innovation. It's also suggested for government to establish phase policy to promote industrial transfer and latecomer's study and innovation.
\end{abstract}

Keywords-technology catch-up; industrial transfer; market entry barrier; bargaining cost

\section{INTRODUCTION}

Under background of reform and opening-up and economic transition, China telecom manufacturing has experienced great change from localization production to independent standard during thirty years. In 2008, third generation mobile communication system of China's standard brought forward by Datang started business deployment; In 2010, Operation Revenues of Huawei and Zhongxin ranked 2 and 5 among global telecom manufactures. Chinese successful case of catch-up in telecom manufacturing becomes example of research on draggling industry's catch-up in developing countries.

From visual angles of nation and industry system, technology system evolution, market structure and competition, and enterprise's development strategy, scholars explored the process of catch-up of Chinese latecomers of enterprises. Liu and Wang considered that hierarchy structure of telecom network and opening interface standard provided good opportunity for catch-up, and study platform of telecoms and posts system accelerated the process of technical spill over and spread to latecomers [1]. Mou and Keun indicated that China's great market made the policy of "market exchange for technology" possible, divisible market provided opportunity for latecomers to meet demands by different products, and government's protection and support brought additional competition to latecomers [2]. Yang suggested that derived production of complicated system favored latecomers to acquire part of market and then reduce difference in technology and market with foregoers [3]. Shen considered China-foreign joint-venture realized technology spill over, and government's technology policy, administration intervention and market power jointly promoted enterprise's technology capability [4]. The research gaps are short of sustentation of mainstream industrial economic theories and logic analysis framework to grasp mechanism and phase character of catch-up. In this paper mainstream industrial economic theories are introduced, logic analysis framework is established, and game theory is applied to analyze internal mechanism among industrial transfer, market structure and catch-up action. Conclusion and suggestion on management and policy are also provided.

\section{INDUSTIAL THEORY AND ANALYSIS FRAMWORK}

\section{A. Industrial Economic Theory}

Industrial economist's gradient shift theory and flyinggeese theory presented that one country should invest from industry in comparative inferior position (marginal industry) and start industrial transfer whose technology and product have minimized difference with those of nations receiving this industry to ensure complementary but not substituted relation between investment and trade [5].

Havard School put forward SCP research model that market structure determines market action, and market action determines market performance. Bain considered market entry barrier to be one important index of market structure and to be of influence on enterprise's conduct and performance. He suggested that scale economy, product difference and advanced technology are all important entry barriers [6].

Coase brought forward in his transaction cost theory that company's internal coordination substitutes for market transaction because negotiation, contract drafting, inspection and dispute arbitration under market mechanism could be 
replaced by management decision on company's internal resource allocation, which reduces transaction cost [7].

\section{B. Logic Analysis Framework of Integrated Theories}

i) Transfer-out country could start industrial transfer only if there is large industrial technical difference between transfer-out country and transfer-in one, and transfer-in country owns industry receiving capacity on technology, human resource and infrastructure. These conditions determine progress and direction of transfer. ii) Investment is one kind of substitution method for trade in obstacle [8]. During transfer process, transfer-out country brings new product into transfer-in country and explores one new market simultaneously. But receiving capacity of transfer-in country and market entry barrier restrict the transfer process. Technology transfer and spill over are necessary means for foregoers to lower technical barrier to latecomers and obey market entry policy of transfer-in country. iii) While foregoers invest in transfer-in country, sole corporation or joint-venture and joint-cooperation are in choices. If transaction cost to acquire production input and sell product in the former organization is higher than internal coordination cost in the latter two, then the latter should be adopted, which is also favoring of technology spill over, or else the former should be adopted.

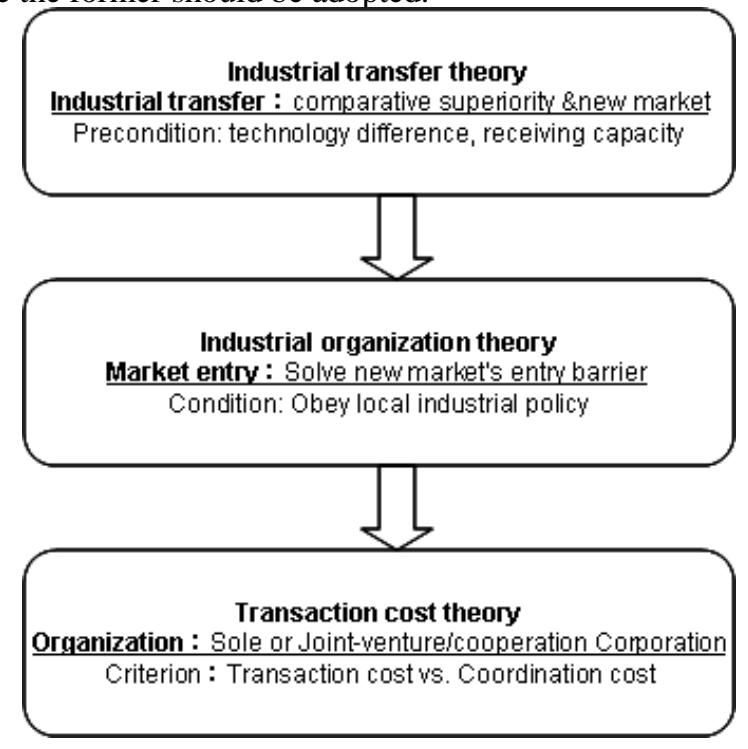

Figure 1. Logic anlysis framework of integrated theory

\section{Phase Process Framework}

According to technical and integrated competition power of latecomers in transfer-in country, catch-up process can be divided to four phases as shown in Fig. 2. (1) Absolute Disadvantage Phase: Latecomers are in absolute disadvantage in technical competition power and integrated one. Since foregoers can use technology barrier and latecomers have domestic market buyer's powers, they adopt cooperation to complement each other. (2) Comparative Disadvantage Phase: Local enterprises master low-end imitation technology and enter low-end product market.
Latecomers still have biggish difference with foregoers in technical and integrated competition power, but own some competition power in low-end product market. (3) Comparative Advantage Phase: Latecomers reduced technology difference through independent research and development. With price superiority, their integrated competition power is close to or even surpasses that of foregoers, and start to explore international market. Weakened technology barrier and entry barrier cause competition to be main selection. (4) Absolute Advantage Phase: Latecomers own competition power in high-end technology and their integrated competition power advantage are obvious, which promoted their extension to advanced countries' market.

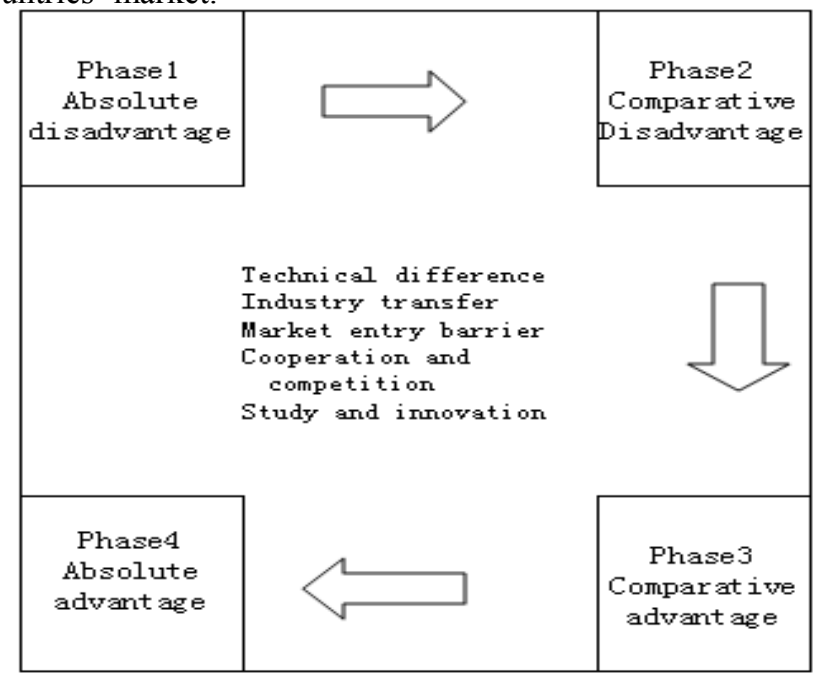

Figure 2. Phase Process Framework

To sum up, in industrial transfer, latecomers make use of opportunity of investment from foregoers to study technology in cooperation, but base themselves upon independent innovation, which is beneficial for durative reduction of difference in management and technology with foregoers. Finally they realize catch-up. In this process, technical difference and policy of market entry barrier exert critical functions.

\section{CATCH-UP PROCESS ANALYSIS}

\section{A. Absolute Disadvantage Phase (1980s)}

Later 1970s, laggard communication manufacturing of China in which cross-bar switching system used by the western before 1960s was still main switching equipment, restricted development of telecom network seriously. And "Paris Coordinating Committee" of the western countries blocked technology output to China, which increased the technology difference. Simultaneously, foreign foregoers could not enter China market freely for high market entry barrier of policy. China government presented new policy of "exchange market for technology" and permitted foreign capital's coming in by forms of joint-venture and jointcooperation, in which China Posts and Telecoms Industry Corporation (Potevio) was accredited exclusively power to 
introduce foreign capital by forms of joint-venture and jointcooperation corporation [9].

In this phase, latecomers were in absolute disadvantage both in technical competition power and integrated competition power. But they owned regulation superiority of market barrier and resource superiority of controlling local market. Consequently, industrial transfer possessed precondition. Since under domestic industrial policy foregoers confronted very high transaction cost, what they could do was to obey the policy, found joint-venture and joint-cooperation corporations with latecomers, and provide technology training and spill over to latecomers to raise their industrial receiving capacity. Finally, domestic production replaced oversea production. Known from analysis by game theory, if latecomer and foregoer all adopt cooperation strategies, Nash equilibrium would be realized and Pareto optimality would also be realized in present condition [10]. Betray strategy from either party would lead to double low payoff as shown in Fig.3. Latecomers made use of spill over directly or indirectly to reduce technology difference and raise industry receiving capacity and foregoers acquired comparative superiority in production and new market. Operation mechanism reform of latecomers and industryschool-institute-user platform promoted study from spill over and technology advance of latecomers.

\section{B. Comparative Disadvantage Phase (1990s)}

Using divided telecom network and price competition, with imitation technology and preliminary development capacity, latecomers competed with foregoers in part of market. Technical difference between them decreased further. For example, in 1991, Potevio developed China's first tenthousand line digital program controlled switching with domestic institute [9]. Along with further opening of domestic telecom manufacturing market, joint-venture and joint cooperation ceased to be the only method for foregoers to coming into this market, and function of joint-venture was cut down by them. Government also adapted their production localization promotion policy to independent development promotion policy [11].

In this phase, latecomers owned technical and integrated competition power to compete in middle-end and low-end product market with foregoers, while their regulation superiority in industry policy and resource superiority in market buyer's power decreased obviously. Reduced technology difference shrunk space of industrial transfer. Foregoers increased grade of introduced technology, but also enhanced control of spill over. Latecomers reduced technology difference more by independent development, which also decreased imminence of need to establish jointventure or joint-cooperation. Confronting competition threat, foregoers might sometime adopt betray strategy to get temporary goodness. But under background of China's independent development promotion policy and technology transfer encouragement policy, keeping cooperation mode could help foregoers to avoid policy risk; simultaneously, domestic enterprises still faced technical barrier in high-end product and wanted to raise technology level by cooperation and study. Similar to Cournot equilibrium, though betray strategy brings temporary benefit, but cooperation brings long term goodness under repetition game. Double cooperation strategy is an unstable Nash equilibrium in the long term, shown in Fig. 3. Market guide reform of enterprise, independent development and industrial platform prompted rise of latecomers' management and technology level and industry receiving capacity.

$$
\begin{aligned}
& \begin{array}{l}
\text { Latecomer } \\
\text { Coperation Betray }
\end{array}
\end{aligned}
$$

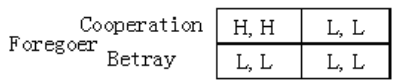

$$
\begin{aligned}
& \text { Phase1: Absolute disadvantage } \\
& \text { Latecomer } \\
& \text { Cooperation Betray }
\end{aligned}
$$

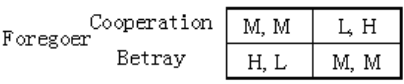

$$
\begin{aligned}
& \text { Phase3: Comparative advarntage } \\
& \begin{array}{c|c|c|} 
& \text { Latecomer } \\
\text { Cooperation Betray } & & \\
\cline { 2 - 3 } \text { Foregoer Cooperation } & \text { M, M } & \text { L, H } \\
\cline { 2 - 3 } \text { Betray } & \text { H, L } & \text { L, L } \\
\hline
\end{array} \\
& \text { Phase2: Comparative disadvancage } \\
& \text { Latecomer } \\
& \text { Cooperation Betray }
\end{aligned}
$$

Note: H, M and L mean high, middle and low respectively, and they are comparison results of payoff of different strategy combinations within one phase.

\section{Figure 3. Game analysis of different catch-up phase}

\section{Comparative Advantage Phase (2000s)}

By utilizing opportunity of delivery and commercial system deployment of China's 3G standard, latecomers intensified their independent innovation capacity and mastered core technology. Magnitude of technology difference became small and integrated competition power of latecomers was close to even surpassed that of foregoers, which brought much competition pressure on foregoers. For example, in 2001, Huawei signed a sale contract on GSM equipment valued more than ten million dollars with Russia, and entered Europe market firstly [12]. Gradually disappearing technical difference caused industrial transfer slowing and stopping. Foregoers enhanced protection of intellectual property protection, and protected their conventional market in advanced countries by market entry barrier. Merge and consolidation between foregoers happened frequently, in which they cut down cost and raised competition power. China's entry to WTO and close of its transition term finally ended this market's entry barrier.

In this phase, industrial transfer gradually stopped, and technology difference and market barrier also gradually disappeared. Since coordination cost in joint-venture was more than transaction cost in sole corporation, foregoers selected sole corporation or holding corporation as operation organizations and prevented technology spill over to harm core competition power. With support from government's independent innovation and core technology breaching policy, industry-school-institute-user platform and market buyer's power, latecomers based themselves upon independent innovation, and benefit from joint-venture or joint-cooperation was limited. In order to keep away the other side's betray, both sides' betray strategies became stable equilibrium, shown in Fig. 3. But under some conditions, they may select cooperation. For example, while developing commercial system of TD-SCDMA, in order to avoid risk from policy and unclear market perspective, 
Siemens and Huawei founded joint-venture. But the cooperation was not stable and confined in part of business. In this phase, industrial transfer only had small promotion on decrease of technical difference. National project fund, buyer's power support, new industry-school-institute-user platform, innovation system establishment and strategy of intellectual property rights significantly promoted latecomers' independent innovation and technology advance.

\section{Absolute Advantage Phase (2010s)}

In this phase, domestic enterprises gradually realize breakthrough in entire industrial chain from chip to equipment, and from software to meter. Owning international competition power of industrial chain, latecomers enhance industrial transfer to other developing countries and will become new foregoers. In this phase, both technical competition power and integrated competition power of latecomers are close to and surpass those of foregoers, and carry out competition in high-end market in advanced countries. For example, in 2010, Huawei and Zhongxin ranked in top 5 telecom manufacturers in operation revenue. Since losing technical advantage, foregoers strengthen market entry barrier of policy in European and North American markets.

In this phase, low transaction cost brought by China's full marketization and low cooperation benefit brought by similar technical level lead to no benefit promotion in cooperation. Betray strategy (full competition) becomes best selection for both sides, which is both stable Nash equilibrium and Pareto optimization, shown in Fig.3. For example, for the $4^{\text {th }}$ generation mobile communication system of China's standard, Siemens (Nokia-Siemens) and Huawei all select independent development and abandon cooperation. In this phase, government's informatization strategy and support policy of strategic new industries provide policy assurance for catch-up and leading of entire industrial train.

Summary of above analysis result of four-phase catch-up process is listed in Table I.

TABLE I. SUMmary of CATCH-UP PROCESS ANALYSIS IN FOUR PHASES

\begin{tabular}{|c|c|c|c|c|c|}
\hline PH & $\begin{array}{c}\text { Technical } \\
\text { Difference }\end{array}$ & $\begin{array}{c}\text { Market } \\
\text { Entry } \\
\text { Barrier }\end{array}$ & $\begin{array}{c}\text { Transaction } \\
\text { cost } \\
\text { vs. } \\
\text { Coordination } \\
\text { cost }\end{array}$ & Action & $\begin{array}{c}\text { Industry } \\
\text { Transfer }\end{array}$ \\
\hline 1 & $\begin{array}{c}\text { Very } \\
\text { large }\end{array}$ & $\begin{array}{c}\text { Very } \\
\text { large }\end{array}$ & Far more & JV and JC & $\begin{array}{c}\text { Start } \\
\text { tranfer-in }\end{array}$ \\
\hline 2 & biggish & biggish & More & $\begin{array}{c}\text { Mainly } \\
\text { JV and JC }\end{array}$ & $\begin{array}{c}\text { Continuous } \\
\text { trafer-in }\end{array}$ \\
\hline 3 & little & little & Less & $\begin{array}{c}\text { Mainly } \\
\text { Competition }\end{array}$ & $\begin{array}{c}\text { Tranfer-in } \\
\text { slowing } \\
\text { and stopping }\end{array}$ \\
\hline 4 & reversion & none & Far less & Competition & Tranfer-out \\
\hline
\end{tabular}

Note: PH, JV and JC mean phase, joint-venture and joint-cooperation respectively.

\section{CONCLUSION AND SUGGESTION}

In conclusion, logic analysis framework of integrated industrial economic theories effectively explains the catch-up process from absolute disadvantage to absolute advantage, and indicates following catch-up conditions, i.e. opportunity of international industrial transfer, regulation superiority from policy of market entry barrier, study opportunity of technology spill over and independent innovation. Above conditions become mature on condition that government controls rhythm of market opening well, establishes reasonable phase policy, constructs industry-school-instituteuser platform and provides support of market buyer's power.

Based on above analysis and conclusion, it's suggested for latecomers to reasonably establish phase target and strategy according to its capacity, industrial policy and development phase, to make full use of study opportunity of industrial transfer and to base themselves on independent innovation to push phase evolvement. It's also suggested for government to establish matched industrial policy and innovation promotion policy according to latecomers' capacity and industry development phase, in order to provide opportunity and stimulation for latecomers' technology development.

\section{ACKNOWLEDGMENT}

Thanks Professor Chen Jiagui and Dr. Guo Chaoxian for their good suggestions on this paper. The author takes sole responsibility for his views.

\section{REFERENCES}

[1] J.-X. Liu and Y. Wang, "Technical factor analysis of Chinese telecom manufacturing in technology study and catch-up", Innovation and Entrepreneurship Management, vol. 3, pp. 1-24, Dec. 2007.

[2] Q. Mu and K. Lee, "Knowledge diffusion, market segmentation and technological catch-up: the case of telecommunication industry in China", Research Policy, no. 34, pp. 759-783, 2005.

[3] Z.-G. Yang, "Study and catch-up of complicated technology-a case of Chinese telecom manufacturing", Beijing: Intellectual Property Rights Press, 2008.

[4] X.-B. Shen, "The Chinese road to high technology - a study of telecommunications switching technology in the economic transition", Basingstoke: Macmillan Press Ltd., 1999.

[5] S.-J. Huang and Q.-H. Huang, "Modern business administrationperspective of change", Beijing: Economy and Management Publishing House, 2007.

[6] J. S. Bain, "Barriers to new competition-their character and consequences in manufacturing industries", Beijing: People's Publishing House, 2012.

[7] R.-H. Coase, "The institutional structure of production", The American Economic Review, is. 4, vol. 82, pp. 713-719, Sep. 1992.

[8] K. Kojima, "Theory of foreign trade", Tianjing: Nankai University Press, 1987.

[9] S. Huan, "Develop creative, achive new refulgence-Potevio's footprint in 90-year course of Chinese Communist", Potevio, no. 15, 2011

[10] H.-R. Varian, "Microeconomics (Advanced Course)", Beijing: Economic Science Press, 1997.

[11] Y.-Z. Chang, "Multiple-way effect of ownership factor in the catchup of the latecomers of enterprises", ICEMSS international conference, in press, 2013.

[12] C. Li and H.-Y. Cui, "International investigation report on Huaweioriginal impulse just to be survive in winter", IT Times Weekly, Oct. 2004 